\author{
BATIA VALDMAN \\ Ben-Gurion University of the Negev (Beer-Sheva, Israel) \\ iD \\ ORCID: https://orcid.org/0000-0001-7024-6442
}

\title{
Переводы польских писателей \\ в русско-еврейской периодике второй половины XIX века
}

Tłumaczenia polskich pisarzy w czasopismach rosyjsko-żydowskich w drugiej połowie XIX wieku

Streszczenie: W drugiej połowie XIX wieku w periodykach rosyjsko-żydowskich ważne miejsce zajmowały tłumaczenia z języka polskiego, obejmujące utwory polskich pisarzy nieżydowskich i recenzje żydowskiego tygodnika "Izraelita". Zainteresowanie tematyką żydowską polskich pisarzy wynika z odwiecznego współistnienia Żydów i Polaków. W Rosji duża populacja żydowska pojawiła się po rozbiorach Polski, kiedy to terytoria zamieszkane przez ludnośćżydowską przyłączono do Rosji. Tematyka żydowska zajmowała centralne miejsce w twórczości Elizy Orzeszkowej, której utwory publikowano w "Russkom jewrieje” i w czasopiśmie "Woschod". Orzeszkowa opisywała życie i charakter Żydów, ich dyskryminację prawną, wzywała do pojednania Polaków z Żydami. Do innych polskich twórców, których utwory ukazywały się w rosyjskojęzycznych publikacjach żydowskich, należeli: Józef Kraszewski, Kamilla Odyniec, Michał Bałucki, Janina Baudouin de Courtenay (Bagnicka), Adam Szymański. Ich dzieła świadczą o judofilskiej orientacji, zainteresowaniu tematyką żydowską, dobrej znajomości specyfiki charakteru i życia Żydów. Dotyczy to przede wszystkim dzieł Orzeszkowej, doskonale obeznanej z tematyką żydowską. Podobnie jest z jej listami, w których pobrzmiewa idea bractwa Żydów i Polaków.

Słowa kluczowe: czasopisma rosyjsko-żydowskie, "Izraelita”, tłumaczenia z języka polskiego, tematyka żydowska w prozie polskiej, życie Żydów, sztetl żydowski

Translations of Polish writers' literary works

in the Russian-Jewish journals from the second half of the 19th century.

Abstract: In the second half of the 19th century in the Russian-Jewish press, translations of Polish writers' literary works occupied an important place in prose. These translations included works of non-Jewish Polish authors and summaries of a Jewish weekly in Polish, "Izraelita". The interest in Jewish subjects among Polish writers is due, first of all, to the long living side by side of Jews and Poles. In Russia, a significant Jewish population appeared after the partition of Poland in 1772, 1793, 1795, when territories with the Jewish population were attached to Russia. The Jewish theme was one of the central themes in the prose of Eliza Orzeszko, whose works were published in "Russkii evrei" (Russian Jew) and the "Voskhod" (Sunrise). She showed the life and character of Jews, their deprived position, called for the unity of Poles and Jews. Other Polish writers whose works were published in Jewish periodical in Russian - Joseph Kraszewski, Camilla Odynets, Mikhail Balutsky, Janina Baudouin de Courtenay (Bagnitskaya), Adam Szymanski. The works of Polish writers testify to their distinguished sympathy to Jews. They sought to show the peculiarities of character 
and life of Jews, with whom they often intersected in ordinary life, to show their deprived position. Most of all, this was realized in the works of Eliza Orzeszko, where she manifested her knowledge of Jewish life. Orzeszko's letters are an evidence of her thorough study of Jewish sources. They are permeated by the idea of brotherhood of Poles and Jews.

Keywords: Russian-Jewish periodical, "Izraelita", Translations from Polish, Jewish Theme in Polish Prose, Jewish life, Jewish stetl

Начиная с первого русско-еврейского издания «Рассвет» (Одесса, 1860-1861), неотъемлемой частью беллетристики этих изданий были переводы на русский язык с иврита, идиша и других языков'. Главным образом, это были переводы произведений, в которых так или иначе затрагивалась еврейская тематика. Преобладали переводы с немецкого языка, что неудивительно, поскольку еврейское Просвещение (Гаскала) пришла в Россию из Германии. Кроме того, многие известные немецкие писатели были евреи и в своем творчестве обращались к еврейской теме (например, Бертольд Ауэрбах, Карл Эмиль Францоз, Леопольд Комперт). Но и переводы с польского языка занимали важное место. Интерес к еврейской тематике у польских писателей объясняется, прежде всего, длительным совместным проживанием евреев и поляков. Значительное еврейское население появилось в России после разделов Польши $(1772,1793,1795)$, когда к Российской империи отошли Белорусская, Волынская, Подольская, Минская, Литовская губернии. К переводам с польского в русско-еврейской периодике относятся произведения польских писателей и обзоры еврейского еженедельника на польском языке «Izraelita», который выходил в Варшаве (1866-1908) и играл важную роль в полонизации евреев. Как отмечал польский социолог Александр Херц, «с начала XIX в. еврейский вопрос был одним из самых популярных в польской журналистике»². В статье рассматриваются переводы с польского только прозаических произведений.

Прежде всего, следует назвать Элизу Ожешко (Ожешкова) (1841-1910), у которой еврейская тема одна из центральных. Она родилась в деревне Милковщизна, недалеко от Гродно. Ожешко большую часть жизни провела в Гродно, польском городке, который отошел к России по третьему разделу Польши В 1795 г. В течение XIX в. процент еврейского населения в городе преобладал ${ }^{3}$. Ведущий представитель позитивизма в поль-

\footnotetext{
Подробнее о русско-еврейской периодике указанного периода см. Б. Вальдман, Русско-еврейская журналистика (1860-1914): литература и литературная критика, Центр изучения иудаики Латвийского университета, Рига 2008.

2 A. Hertz, The Jews in Polish Culture, Northwestern University Press, Evanston 1988, p. 203.

3 Краткая Еврейская Энциклопедия, Общество по исследованию еврейских общин, Иерусалим 1982,
} 
ской литературе, Элиза Ожешко отмечала большую роль и влияние польского восстания 1863 г. на ее творчество и духовный мир ${ }^{4}$. Именно после этого восстания на смену романтизму в ее творчестве пришел позитивизм, который привнес в польскую литературу усиление реалистических тенденций, характерных для творчества писательницы.

В письмах к одному из главных сотрудников еженедельника «lzraelita» Адольфу Кану она подробно и искренне пишет о месте еврейской темы в ее творчестве ${ }^{5}$. В первом письме из Гродно (декабрь 1876 г.) отмечает, какое «огромное значение» она придает изучению еврейского бытаб ${ }^{6}$ А потом с горечью добавляет:

Доныне польское общество руководится в своих суждениях об одной из самых интересных, даровитых и влиятельных частей населения страны какими-то преданиями и различными предрассудками. Никто не попытался проникнуть в глубь ее морали и умственной жизнит.

Интересно, что в этом же письме Ожешко пишет, что «еврейство является для нас всех каким-то неразгаданным сфинксом, тайну которого каждый пытается по-своему объяснить и разгадать». В этом первом обстоятельном письме, которое, как и последующие, позволяет проникнуть в лабораторию ее творчества, Ожешко признается, что в тот момент, когда у нее «возникло решение написать ряд повестей», посвященных быту евреев, она обратилась к редактору журнала «Izraelita» Пельтыну «за советами и указаниями» и начала основательно изучать талмудическую литературу, еврейскую историю и среду ${ }^{9}$. Первым произведением на еврейскую тему стала повесть Эли Маковер. Отрывки из нее публиковались в «Русском еврее» в 1880 г. (1-4, 6, 7, 10-12). В роли переводчика выступил один из первых прозаиков русско-еврейской литературы Лев Леванда (1835-1888), он же являлся автором предисловия к публикации в «Русском еврее». В этом предисловии Леванда подчеркивал «глубокий социальный смысл», свойственный творчеству писатель-

T. 2, C. 229.

4 См. 06 этом в книге: M. Opalski, I. Bartal, Poles and Jews: A Failed Brotherhood, Brandeis University Press, Henower, L.H. 1992, c. 6.

513 писем 0жешко к Адольфу Кану были опубликованы в «Еврейской старине» 1914, выпуск 1, С.-Петербург 1914. Они охватывают период с 1876 по 1883 гг.

6 «Еврейская старина», с. 44

7 Тамже.

8 Тамже.

9 Там же, с. 44-45. 
ницы $^{10}$. Леванда отмечал, что в польской литературе всегда в эпизодах присутствовали еврейские типы - в основном, это были шинкарь и арендатор, но о еврейском быте в польских произведениях не могло быть и речи"1. В произведениях Юлиана Немцевича и Игнацы Крашевского заметно, по крайней мере, желание авторов рисовать «не только еврейский характер, но и еврейский быт»12. Однако, по мнению Леванды, только роман Эли Маковер явился:

первой попыткой в польской литературе рисовать еврейский характер, еврейский быт и отношение евреев к народности, между которой они живут... серьезно, объективно и с очень благородной целью. Цель эта примирение обеих национальностей путем взаимного понимания и уважения, примирение равных с равными ${ }^{13}$.

В этих словах Леванды почти дословная цитата из окончания романа, в котором поляк Мечислав и еврей Эли ведут беседу на равных и говорят о взаимном уважении. Роман Эли Маковер (был издан в Варшаве в 1876 г.) рассказывает о польских помещиках, живущих в Северо-Западном крае, где евреи больше общались с поляками, чем с русскими. Опубликованные в «Русском еврее» отрывки из романа озаглавлены Три поколения, т.к. в романе показаны три поколения евреев в соответствии с тремя периодами пережитой и переживаемой эпохи. Эти поколения символизируют старый портной Юдель, отец многочисленного семейства, один из сыновей которого Эли - тип современного энергичного арендатора, и сын Эли - Абрамка Готлиб. Впервые в центре внимания польского писателя оказалась судьба евреев, к которым Ожешко относится с сочувствием и уважением, знает и изображает их и хорошие, и дурные стороны, видит в них «интеллигентную и экономическую силу». Именно этот момент как главную заслугу писателя подчеркивает в своем предисловии Леванда. Основные качества романа, принципы подхода к изображению евреев подробно рассмотрены в статье критика «Русского еврея» Гершона бен Гершона ${ }^{14}$ Евреи - арендаторы и польские помещики в Северо-Западном крае. Рецензент отмечает исключительное, «до тонкостей», знание Ожешко

14 Псевдоним писателя Григория Лифшица (1854-1921), активного сотрудника русско-еврейской периодики.
} 
жизни, которую она изображает. Роман этот - «снимок с будничной повседневной жизни известного класса людей со всеми их национальными особенностями» - пишет Гершон бен Гершон ${ }^{15}$. Он справедливо считает, что Эли Маковер это, собственно, и не герой романа, поскольку Ожешко не очень-то интересуют его чувства. Она хотела написать «повесть борьбы из-за презренного металла», и здесь-то Эли, благодаря своему уму и энергии является первым лицом ${ }^{16}$. Ожешко вообще важно изобразить “обыкновенную жизнь», а не героев и эффектные сцены, она умеет увлекательно говорить о мелочах, в том числе о мелочах еврейской жизни ${ }^{17}$. Софья Дубнова - Эрлих ${ }^{18}$ отмечала в своей статье об Элизе Ожешко способность польской писательницы увидеть тип еврея-идеалиста, намеченный в образе Юделя, а позднее более подробно разработанный в новелле Гедали ${ }^{19}$.

В том же 1880 г. в «Русском еврее» $(5,6,8,9)$ был опубликован рассказ Ожешко Дай цветок! В центре рассказа бедная старьевщица Хая и ее внук, который однажды впервые увидел цветы в руках польской пани. В еврейской части города они не росли. Подаренные ему цветы, мальчик воспринял как ценный дар. В этом небольшом рассказе проявилась характерная черта Ожешко - любовное отношение к униженным. В рассказе упоминается ребе Нохум - характерный тип еврейского учителя, в котором окружающие видят настоящего праведника. К нему Хая приводит своего внука. Оказывается жил в Гродно такой праведник раввин Нохум Каплан (18121879), которого Элиза Ожешко увековечила в своем рассказе. Ожешко пишет, что он был известен среди еврейской бедноты своей ученостью, набожностью и милосердием ${ }^{20}$. Полное имя переводчика рассказа не названо, указаны лишь инициалы К.О. В Систематическом указателе литературы о евреях инициалы расшифрованы - Камилла Одынец ${ }^{21}$.

15 «Русский еврей» 1880, № 12, с. 468.

16 Тамже.

17 Там же, с. 470.

18 Софья Дубнова-Эрлих (1885-1986) - поэтесса, переводчик, литературный критик; дочь еврейского историка и публициста Шимона (Семена) Дубнова (1860-1941).

19 См. Еврейская Энциклопедия Брокгауза и Ефрона в 16 томах, Издательство Брокгауза и Ефрона, С.-Петербург 1912, т. 12, стб. 132.

20 См. М. Кемеров, 0. Соболевская, Праведник из Гродно // Евреи Гродно. Очерки истории и культуры, Гродно 2000, с. 92.

21 Систематический указатель литературы о евреях на русском языке со времен введения гражданского шрифта (1708 г.) по декабрь 1889, Типо-литография А. Е. Ландау, С.-Петербург 1893, с. 539; И.Ф. Масанов, Словарь псевдонимов (в 4 томах), Всесоюзная книжная палата, Москва 1956, т. 2, с.17; Камилла Одынец указана как автор в изданиях «Неделя» и «Русский еврей». 
Работая над статьей об отношении Ивана Тургенева к погромам 1881-1882 гг. в России ${ }^{22}$ я обнаружила среди адресатов русского писателя этого периода Камиллу Одынец, которая обращалась к нему за содействием в публикации ее произведения (Тургенев оказал ей и материальную помощь). В статье Елены Левиной К истории знакомства И.С. Тургенева с К. Одынец собраны редкие сведения об Одынец из архивов Москвы и С.-Петербурга. Помимо шести писем к Тургеневу, там имеется рукопись Одынец Важнейшие факты из моей биографии 23 . Из этой рукописи следует, что Камилла Ивановна Одынец дальняя родственница польского писателя Антона Эдуарда Одынца. Родилась где-то в начале 50-х годов (точные даты ее рождения и смерти не установлены). Она выросла в религиозной католической семье, затем приняла православие и уехала из Варшавы в Петербург примерно в 1877, где оказалась без средств к существованию ${ }^{24}$. Как сказано в статье Левиной, журналистку спасла от голодной смерти редакция журнала «Русский еврей», предложившая ей сделать несколько переводов $^{25}$. Благодаря протекции Тургенева Одынец готовила для «Вестника Европы» статью о Элизе Ожешко и перевод одного из ее романов.

Переводы произведений Ожешко публиковались, главным образом, в журнале «Восход», который начал издаваться в 1881 г. в С.-Петербурге. Это рассказы Гедали и Момент, этюд Звенья, исторический роман Миртала. Кроме того, был опубликован перевод статьи писательницы, которой открывался в 1880 г. «Еврейский календарь», издаваемый в Варшаве на польском языке. Таким образом, почти все главные еврейские произведения Ожешко впервые на русском языке появились в периодике, кроме романа Меир Езофович (его русский перевод сразу вышел отдельным изданием в С.-Петербурге в 1882 г.).

В своих рассказах Ожешко показала еврейского бедняка, сохранившего душевную чистоту, несмотря на все жизненные невзгоды. Именно таким предстает Гедали из одноименного рассказа $(1885,1,2)$ в переводе Ростислава Сементковского 26. Этот бедняк, больной чахоткой, торговец незатейливых това-

22 См. Б. Вальдман, И.С.Тургенев и русско-еврейская периодика второй половины 19 - начала 20 вв. // Евреи России, Европы и ближнего Востока: история, культура и словесность, Петербургский Институт иудаики, С-Петербург 2019.

23 Е.Н. Левина, К истории знакомства И.С. Тургенева с К. Одынеи, «Спасский вестник» [0рел] 2000, вып. 7, с. 113-119.

24 Там же, с. 114.

25 Там же, с. 115.

26 Ростислав Сементковский (1846-1918) - писатель, публицист, переводчик. 
ров, вызывает симпатию польской семьи Корейбы. Ядвига нашла покупателей, и у него оказался неожиданный заработок. В рассказе нарисована довольно идеальная картина, но писательница изобразила то, о чем всегда мечтала - торжество добра и справедливости, единение поляков и иудеев. Заслуга Ожешко в том, что она создала характерный образ простого еврея Гедали, одного из тех, кого она встречала, живя в Гродно и Вильно. В предисловии к рассказу отмечалось:

еврея принято изображать в карикатурном виде. Его не изучают; над ним изощряют свое остроумие. К тому же в романах и повестях обыкновенно берется еврей, вышедший из своей среды, покинувший свою родину и вращающийся в обществе христиан. Элиза Ожешко наблюдает еврейскую жизнь в самом ее центре, там, где... скучено множество евреев ${ }^{27}$.

Близок Гедали по своей направленности этюд (так определяет жанр произведения сам автор) «Звенья» $(1896,1)$. Здесь есть образ старого еврея - часовщика Берко. Несомненно, он отличается от Гедали, в нем есть склонность к философствованию. Да и вся тональность рассказа другая. К Берко приходит починить часы такой же старый, как он, польский граф. Они знали друг друга в юности. Оба к старости оказались одиноки и размышляют о прошедшей жизни. Удивительные часы в доме Берко, которые захотел купить граф, выступают как символ прошедшего времени, как напоминание о лучших временах жизни. Когда Берко отказывается их продать, граф удивленно восклицает: «Ведь ты не богат и притом еврей, а что же у евреев может быть дороже денег?»²8. И Берко рассказал, как сорок лет назад, увидев эти часы — кукушку, выздоровел его любимый сын, и в доме радостно смеялись и танцевали все его дети. Новые встречи и беседы Берко и графа постепенно соединяли этих разных людей какими-то звеньями. После смерти графа Берко увидел, что еврейское и христианское кладбища находятся рядом и их как бы объединяет общий небосклон. Все та же мечта писательницы о братском единении евреев и поляков.

В рассказе Момент $(1899,5)$ Ожешко как бы проникает в душу простых евреев заброшенного еврейского местечка, где на постоялом дворе случайно оказалась певица. Ее изумительное пение вызывает из глубин души местечковых ев-

27 «Восход» 1885, № 1, с. 35. Кстати, в предисловии говорится о романе из еврейского быта Меир Езофович, который «доставит ей, в чем нельзя сомневаться, европейскую известность, когда на днях появится на немецком языке в Берлине» (см. там же).

28 «Восход» 1896, № 1, с. 76. 
реев самые возвышенные чувства. Только что Рухля о чем-то спорила с мужем и вдруг, услышав пение, «заговорила тихо и мягко» и предложила мужу выйти на крыльцо, чтобы лучше слышать. Здесь они одновременно обратили внимание на красивую луну. В другом доме «серьезный Хаим и его жена Малка подняли голову от расчетной книги и, как жившие дружно супруги, в один голос произнесли: Как хорошо поет кто-то! И они тоже восхитились светом луны. А пение проникло им в самое сердце» ${ }^{29}$. Этот рассказ был опубликован с пометкой «перевод с рукописи В.Л.» в «Русской мысли» $(1899,1)$, а позднее в журнале «Русское богатство» $(1901,6)$ в переводе Зинаиды Журавской. В конце 90-х гг. рассказы Ожешко носят явно философский характер.

Одной из интереснейших исторических повестей в «Восходе» является повесть Ожешко Миртала $(1888,1-6)$ в переводе Адама Онуфровича. В этом же году повесть вышла отдельным изданием в С.-Петербурге на русском языке. Ее действие развертывается в Риме после победы римлян в Иудейской войне, а точнее через два года после того, как Тит превратил Иерусалим и Храм «в груду развалин» ${ }^{30}$, т.е. в 72 г. н.э. В повести есть исторические личности: Тит, Веспансиан, Береника, Иосиф Флавий и др. (например, молодой историк Тацит!), но они статичны, а действуют, в основном, вымышленные персонажи: Менахим, который разыскивал в Риме и в Эфесе находящихся там в рабстве еврейских детей, его приемная дочь, красавица Миртала, спасенная из рабства, борец за свободу Иудеи Ионатан, римлянка Фанни и др. С первой страницы повести чувствуется, что Ожешко прониклась описываемой эпохой, проблемы и события далекой истории связаны у нее с проблемами современности. Стремление древних иудеев к независимости, к свободе, гордый характер лучших представителей народа ассоциируются у писательницы с устремлениями евреев конца XIX в. Характер Менахима проявляется в замечательной сцене его беседы с секретарем Агриппы Юстом, который предлагает ему должность секретаря у Иосифа Флавия. Должность сулит прекрасное жалование, хорошую квартиру, возможность обеспечить будущее Мирталы. Но на все это Менахим отвечает отрицательно, и только, когда Юст начал говорить о Ионатане, он закричал, чтобы Юст не искушал его ${ }^{31}$. Когда арестованного Ионатана ожидает казнь, Менахим про-

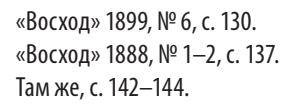


износит страстный монолог, просит отпустить Ионатана и принимает всю вину на себя: «Это я ходил в Иудею на войну против вас... Я сражался с вами... Я поднял бунт в Египте, я был в амфитеатре...»32. При этом автор обращает внимание на тощие плечи Менахима, обнаружившиеся из-под разорваннной одежды, а рядом могучими спинами выделялись римляне. Образ Менахима по силе страстной отцовской любви, по величию духа напоминает шекспировских героев. Интересен и образ главной героини Мирталы с огненного цвета волосами, рожденной в рабстве в Греции. Родиной ее родителей была Галилея. Это талантливая девушка, но она отказывается от предложение Артемидора, который хочет ее обучать живописи, отказывается остаться у Фанни и возвращается в гетто. Правда, какое-то время Миртала сомневается, но в решающий момент, когда Ионатана ведут на казнь, она оставляет Артемидора и бежит к Ионатану: «Я с ним... с тобой, несчастный мой народ!»33. Миртале противопоставлена еврейка Береника, которая прельстилась роскошью и готова стать женой Тита. Ионатан - это герой, борец за свободу своего народа, в то же время его душу и сердце переполняет страсть к Миртале. На празднике на Марсовом поле он произносит проклятие Титу, «разорителю чужих земель», и Беренике, «изменнице правому делу, отравительнице душ иудейских дочерей». Перед смертью на площади Ионатан убивает Мирталу, когда увидел бросившегося к ней римлянина. «О странная генеалогия безумств, порожденных несчастием, и преступлений, проистекающих из несправедливости человеческой!» - заключает Ожешко этот эпизод ${ }^{34}$. В повести есть еще один замечательный образ - это Рим, на фоне которого развиваются события, с его холмами и площадями, храмами и великолепным Тибром, который делит город на Затибрское предместье, где живет еврейская беднота, и другую часть, где «на семи холмах все святыни города и обитают властелины мира» ${ }^{35}$. Прекрасно передана атмосфера города - оживленная торговля, прогулки философов с учениками, праздник на Марсовом поле. И сегодня эта повесть читается с большим увлечением.

Главная идея статьи Ожешко из «Еврейского календаря» - «тормозы слияния евреев с коренным населением» («Восход»,1881, 11). Это идеал писательницы, который отразился во многих ее произведениях:

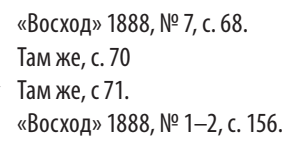


слияние двух населений, обитающих на земле нашей: христианского и нехристианского, в одно мирное и соединенное целое, слияние, которому широким и прочным фундаментом служили бы здравое понимание общей пользы, а также чувства справедливости и благожелательности ${ }^{36}$.

Ожешко считает, что для достижения этого идеала нужно, во-первых, просвещение еврейского народа и христиан, совместное их обучение в средних и высших школах «под крылом одной речи, одних прав и одинаковых устремлений» ${ }^{37}$. Во-вторых, необходимо заключение браков между представителями обеих народностей для скорого исчезновения расовых различий. Естественно, эти цели ведут к полной ассимиляции евреев, к их полонизации, чьей сторонницей была Ожешко.

В 1910 г. Ожешко умерла, и в 5-м номере «Еврейской недели» был опубликован некролог И. Клейнмана. Он писал об особом месте польской писательницы среди друзей и защитников евреев. Развернутую характеристику творчества писательницы дал литературный критик Аркадий Горнфельд в статье Памяти Элизы Ожешко в 6-м номере «Еврейской недели». Отметив определенную тенденциозность ее первых произведений, Горнфельд писал: «Но вскоре настоящий художник взял верх, и миру предстало редкое по гармонии сочетание подлинного художественного дарования, ясной и твердой мысли и большого любящего сердца» ${ }^{38}$. Горнфельд подчеркивал главное достоинство произведений Ожешко: в них не жалость, не снисхождение, не сострадание к евреям, а уважение к человеческому достоинству, умение заглянуть в их душу и раскрыть нечто новое самим евреям. Последняя незаконченная статья Ожешко по еврейскому вопросу согласно ее воле после смерти была помещена одновременно в идишском «Hajnt» и в польском «Kurjer Warszawski» в 1911 г. В «Новом Восходе» $(1911,41,42)$ сразу же появился отклик Клейнмана Недописанное завещание Э.Ожешко, где он отмечал ее искренне-доброжелательное отношение к еврейскому народу.

Следует отметить, и высокую оценку, которую дал Ожешко писатель Михаил Салтыков-Щедрин в своей статье Июльские веяния, в значительной степени посвященной еврейскому вопросу. Статья была опубликована в августовской книжке «Отечественных записок» за 1882 г. (в этот период Салтыков-

\footnotetext{
6 «Восход» 1881, № 11, С. 59.

37 Там же, с. 67.

38 «Еврейская неделя» 1910, № 6, ст6. 23.
} 
Щедрин был редактором журнала, и здесь публиковались все его произведения). В статье Салтыков-Щедрин отмечает «прелестный рассказ г-жи Оржешко Могучий Самсон» ${ }^{39}$. «И те, которые пожелают узнать, сколько симпатичного таит в себе это племя и какая страшная трагедия тяготеет над ним, - пусть обратятся к этому рассказу, каждое слово которого дышит правдой» ${ }^{40}$.

В «Русском еврее» было опубликовано два произведения Камиллы Одынец, о которой речь шла выше. И здесь ее произведения подписаны инициалами К.О. В рассказе Ревекка (1879, 7) чувствуется влияние Ожешко. Это романтический рассказ о трагический любви поляка и еврейки. В рассказе есть реалистическая деталь: цветы, принесенные на могилу Ревекки, не растут в еврейской части города, такая же деталь присутствует в рассказе Ожешко Дай цветок!, который она переводила на русский язык. Можно упомянуть второе произведение К.О., опубликованное в «Русском еврее», - историческая повесть Эсфирь (1880, 27, 30, 33-4, 39, 44, 47, 50, 52; 1881, 3, 6, 10) из жизни евреев в Салониках ${ }^{41}$. Это достаточно посредственное с художественной точки зрения произведение.

В «Восходе» публиковался рассказ еще одной польской писательницы Янины (Ромуальды) Багницкий (1857-1935) более известной по фамилии мужа Бодуэн де Куртенэ, известного лингвиста ${ }^{42}$. Уроженка Киевской губернии, Багницкая закончила историко-филологическое отделение Бестужевских курсов. Она публиковалась в многочисленных периодических изданиях. Рассказ Измаил $(1899,11,12)$ повествует о христианском юноше, воспитанном в уважении к евреям. Однажды он попадает в еврейский квартал, где его оскорбляют пьяные рабочие, приняв за еврея. С этого момента он задумался о судьбе евреев, а потом неожиданно узнал, что является евреем и его воспитала приемная мать. Это открытие привело юношу к решению вернуться к еврейству: «Итак, я еврей. Попытаюсь же быть честным евреем... ренегатом я не буду» ${ }^{43}$. Измаил уехал в еврейское местечко, стал учителем, испытал на себе, что такое антисемитизм. В конце концов, он уехал в Эрец-Исраэль. И если первая часть рассказа написана в реалистическом сти-

39 Могучий Самсон Элизы Ожешко был опубликован в «0течественных записках» в 1880, кн. 12.

40 Цитируется по: Литературное наследство (сборник посвященный М.Е. Салтыкову-Щедрину), Жур.газ. объединение, Москва 1933, т. 11-12, с. 292.

41 Следует отметить, что в 1880 г. есть лишь пометка «перевод с польского», без указания автора, в 1881 г. указаны инициалы K.0.

42 CM. Słownik pseudonimów pisarzy polskich, Zakład Narodowy im. Ossolińskich, Wrocław 1996, т. 4, c. 32.

43 «Восход» 1899, № 11, с. 37. 
ле, то вторая, действие которой происходит в Эрец-Исраэль, - явно в возвышенных, романтических тонах. Например, виолончель, на которой он учился играть в юности, вдруг заиграла в его руках необыкновенные еврейские мелодии. Рассказ интересен своей первой, реалистической частью, где хорошо переданы психологические переживания Исмаила и его приемной матери. Рассказ Багницкой проникнут ярко выраженной юдофильской направленностью.

К числу известных польских писателей XIX в., проявлявших значительный интерес к еврейской теме, относится Иосиф Крашевский (1812-1887), редактор «Gazeta Polska» с 1859 г., в которой он проводил идею равноправия евреев. Как отмечает в статье о Крашевском Клейнман, польского писателя интересовали проблемы борьбы старого еврейства с просвещением и вопрос общения и слияния евреев с поляками на почве общих гражданских и духовных идеалов ${ }^{44}$. И еще одна проблема, связанная с еврейством, интересовала писателя - зарождение еврейской буржуазии, новый образ жизни евреев, вырвавшихся за рамки гетто ${ }^{45}$. Об интересе Крашевского к еврейской теме свидетельствует сделанный им перевод с еврейского рукописи о графе Потоцком, который разочаровался в католичестве и перешел в иудейство. Крашевский писал:

Оригинальную рукопись приобрел я на вес золота, а, может быть, и того дороже, и должен был обещаться, что не выдам, от кого я ее имею; я перевел рассказ с помощью г. Александра Элленбогена. Несколько мест я вынужден был опустить. Рассказ написан на чистом еврейском языке ${ }^{46}$.

Этот анонимный текст под названием Гер Цедек (так именует перешедшего в иудейство графа Потоцкого неизвестный автор), с подзаголовком Быль XVIII, был взят из книги Крашевскоro Wilno od początków jego do roku 1750 (т. 3, 1841) и переведен на русский язык. Перевод был опубликован в «Еврейской библиотеке» $(1873,3)$. Как свидетельствует Крашевский ${ }^{47}$, в Вильно высоко чтут память Абрагама Абрагамовича, который, разочаровавшись в католицизме, принял в Амстердаме иудейство, а затем вернулся в родные места. И когда в нем узнали бывшего знатного поляка, он был сожжен. Есть в этом тексте еще один герой - сын пана Зарембы, который вместе с Потоцким

\footnotetext{
44 Еврейская Энциклопедия Брокгауза и Ефрона..., т. 9, ст6. 826.

45 См. 06 этом в: M. Opalski, I. Bartal, Poles and Jews..., c. 26-27.

46 «Еврейская библиотека» 1873, № 3, с. 229.

47 Цит. по: Еврейская Энциклопедия, С-Петербург 1910, т. 6, ст6. 429-430.
} 
учился в Париже. И Заремба вместе со своей любящей женой, прожив длительное время в Амстердаме, приняли иудейство, а затем уехали в Палестину. Быль написана в жанре поучительной повести.

Рассказ польского писателя Михаила Балуцкого (1837-1901) дважды публиковался в «Восходе» в разных переводах. Первый раз в 1882 г. (4-5) под названием Типичная еврейка с подзаголовком Картинка с натуры без указания переводчика, и в 1888 г. (8) под названием Старая Мошкова с подзаголовком «Очерк» и с указанием переводчика - Адам Онуфрович. Публикация одного и того же произведения в одном издании - исключительный факт в русско-еврейской журналистике. Второй вариант более лаконичен и точен, поэтому рассмотрим рассказ по второму варианту. Его героиня - достаточно характерный тип пожилой еврейской женщины, которая всех знает, в курсе всех дел еврейского местечка, которой все доверяют. Она занималась мелкой торговлей вразнос. Ее зять, «блестящий господин», стеснялся старой еврейки, однако услышав о сделанном ею завещании, начал за ней усиленно ухаживать. Перед смертью, когда Мошкова сообщила, где находится завещание, «на посинелых губах ее мелькнула насмешливая улыбка, направленная к зятю» ${ }^{48}$. В завещании были лишь слова прощения обид. Следует отметить, что Балуцкий неоднократно обращался к еврейской теме.

В 12 номере журнала «Восход» за 1886 г. есть публикация Адама Шиманского Сруль из Любартова с подзаголовком Из недавних воспоминаний о Сибири ${ }^{49}$. Интересно, что этот же очерк Шиманского был опубликован в «Одесском Вестнике» $(1888,139)$ и «Русском курьере» $(1888,127)$. Адам Шиманский (Шиманьский) (1852-1916), писатель, юрист и этнограф, за участие в польском национальном движении был сослан в ссылку в Сибирь. Здесь он изучал географию и этнографию Якутского края, стал членом Российского императорского географического общества. В Якутске он писал рассказы из жизни ссыльных поляков, «стал первым в польской беллетристике певцом Сибири» ${ }^{50}$. Сруль из Любартова - один из «сибирских» расска-

48 «Восход» 1888, № 8, с. 93.

49 В.Г. Короленко в книге История моего современника в главе XXII Моя поездка в Якутск. Польский писатель Шиманский пишет о встрече с польским писателем и упоминает рассказ Сруль из Любартова, где характерная для него тема тоски по родине - Польше «мастерски преломляется в душе еврея». Цитируется по электронной публикации: http://dugward.ru/library/korolenko/korolenko_istoria_moego_sovremennika4.html\#a022 [1.09.2020].

50 См. Б.С. Шостакович. Шиманьский (Шиманский) Адам // Историческая энциклопедия Сибири (в трех томах), http://irkipedia.ru/content/shimanskiy_shimanskiy_adam_istoricheskaya_enciklopediya_sibiri_2009_[25.04.2020]. 
зов - написан в 1885 г. Сруль - польский еврей из Любартова, недалеко от Люблина. Он уже 3 года в Сибири, и, узнав, что в Якутске появился поляк из Варшавы, пришел к Шиманскому поговорить. Видно было, как его переполняет тоска по родной земле, ее полям и лугам, на его измученном лице даже выступили слезы.

Переводы польских писателей в русско-еврейской периодике свидетельствуют об интересе их создателей к еврейской теме. Польские писатели стремились показать бесправное положение, особенности характера и быта евреев, которых было немало в Польше, с которыми они пересекались в обычной жизни. Более всего это реализовалось в творчестве Элизы Ожешко. Автор литературного обзора в журнале «Еврейская жизнь» отмечал в связи с 40-летием литературного творчества Ожешко:

В тяжелой атмосфере еврейской действительности она улавливает не только стоны, но и гордые, полные веры мечты. В Могучем Самсоне и многих ее маленьких эскизах мощь духа лишь более ярко вырисовывается, благодаря унылой и гнетущей обстановке, в которой проходит жизнь ее маленьких героев ${ }^{51}$.

В художественных произведениях, письмах и публицистике Ожешко прозвучал страстный призыв к единению поляков и евреев.

51 Литературная летопись, «Еврейская жизнь» 1906, № 8-9, с. 186. Статья подписана псевдонимом «Елиз. Абр.». Этот псевдоним принадлежит Елизавете Абрамовне Хотинской-Мощенко (после крещения - Николаевна). См. Деятели революционного движения в России // Био-библиографический словарь, т. 2. (Семидесятые годы), вып. 3., Москва 1931, стб. 978. 